\title{
Synthesis, Identification and Surface Active Properties of Some Nonionic Surfactants Containing Quinazolinone Ring.
}

\author{
Suaad M.H. Al-Majidi and Haider M.M. Al-tamimy \\ Department of Chemistry, College of Science / University of Baghdad, Iraq
}

\begin{abstract}
This research includes synthesis of new heterocyclic derivatives of quinazolinone and studying the possibility for their application as surfactants. The preparation process started by the reaction of pentadecanoyl chloride with anthranilic acid gave 2-pentadecyl-4H-benzo[3,1]oxazin-4-one [1] which was used as starting material to synthesis some heterocyclic compounds by a reaction with nitrogen nucleophiles. Compound [1] as starting material reacted by three ways. The first way react Compound [1] with semicarbazide, thiosemicarbazide and phenylsemicarbazide in pyridine as solvent to obtained [1-(4-oxo-2pentadecylquinazolin-3(4H)-yl) urea [2], thiourea [3], phenylthiourea [4] respectively]. The second way include the reaction of Compound [1] with 99\% hydrazine hydrate to produce 3-amino-2-pentadecylquinazolin4(3H)-one [5], then converted to amino derivatives [6-8] by the reaction of Compound [5] with different halogenated compounds such as (benzoyl chloride, acetyl chloride and chloro acetyl chloride) in DMF and pyridine as catalyst. The third way include the reaction of compound [1] with different substituted amine and amide compounds (thiourea, hydroxylamine hydrochloride, glycine, ammonium acetate and phenyl hydrazine) respectively to obtain derivatives of quinazoline [9-14]. The produced compounds [2,4,5,7 and 12] react with propylene oxide in different moles ( $n=3,5$ and 7$)$ to yield novel groups of nonionic compounds having a function as surface active agents. The surface active properties like surface tension and interfacial tension, wetting time, cloud point, emulsion stability, foam height and CMC of these compounds were measured and showed a pronounced surface activity, good emulsifying properties and highly foaming in some of these compounds. Newly synthesized compounds were identified via spectral methods; their [FTIR and some of them by ${ }^{I} H N M R$, $\left.{ }^{13} \mathrm{C}-\mathrm{NMR}\right]$ and measurements of some of its physical properties.
\end{abstract}

Keywords: Quinazolinone derivatives, surface active agent, nonionic surfactant,

\section{Introduction}

Nonionic surfactant is one of the most important groups of surfactant with growing industrial interest and can by synthesized by the ethoxylation or propxylation (addition of ethylene oxide or propylene oxide) of hydrophobic organic compounds containing active hydrogen in the presence of catalyst such as $\mathrm{KOH}^{(1)}$

Quinazolinone derivatives which may have pharmaceutical and industrial applications ${ }^{(2)}$. These derivatives are the subject of many research studies due to their widespread potential biological activities such as antimicrobial ${ }^{(3)}$, anti-inflammatory ${ }^{(4)}$, antitumor ${ }^{(5)}$ anticancer ${ }^{(6)}$ corrosion inhibitors ${ }^{(7)}$ and anti-oxidant ${ }^{(8)}$. This led us to synthesis of novel group of nonionic surfactant containing this nucleus from long chain fatty acid (palmitic acid). Some of the synthesized compounds which have active hydrogen atom were subjected to react with propylene oxide by different moles $(\mathrm{n}=3,5$ and7) to produce nonionic compounds.

The main objective of this investigation is to synthesis and identification of new surface active agents containing quinazolinone nuclei and studies the surface active properties as surface tension and interfacial tension, wetting time, cloud point, emulsion stability, foam height and CMC.

\subsection{Materials and Instruments}

\section{Experimental}

Chemicals used in this work are supplied from BDH, Fluka, Merck and Sigma Aldrich companies and used without further purification. Melting points were uncorrected and registered via digital Stuart scientific SMP3 melting point device .Thin layer chromatography (TLC) used to check purity and homogeneity of synthesis compounds. FTIR spectra of the compounds in the (4000-600) $\mathrm{cm}^{-1}$ spectral range were recorded on SHIMAZU FTIR-8400 Fourier transform Infrared spectrophotometer using KBr discs. ${ }^{1} \mathrm{HNMR}$ and ${ }^{13} \mathrm{CNMR}$ spectra were recorded on Bruker, Ultrasheild (300) MHz in Jordan and (500) MHz in Iran, using TMS as internal reference and DMSO- $\mathrm{d}_{6}$ as a solvent.

\subsubsection{Synthesis of 2-pentadecyl-4H-benzo[1,3]oxazin-4-one ${ }^{(9)}$ [1].}

To a stirred solution of anthranilic acid $(1.37 \mathrm{gm}, 0.01 \mathrm{~mole})$ in dry acetone, palmitoyl chloride $(3 \mathrm{ml}$, $0.01 \mathrm{~mole}$ ) was added in presence of pyridine as solvent. The mixture was refluxed for $3 \mathrm{hrs}$ then concentrated under vacuum. The solid product that separated on cold was filtrated off, dried and crystallized from petroleum- 
ether. The product was heated for $4 \mathrm{hrs}$ under reflux in acetic anhydride then concentrated under vacuum. Physical properties of compound [1] are listed in Table (1).

2.1.2 Synthesis of 1-(4-oxo-2-pentadecylquinazolin-3(4H)-yl) urea [2], thiourea [3], phenyl thiourea ${ }^{(10)}$ [4]: To a solution of compound [1] (3.57gm, $0.01 \mathrm{~mole})$ in $30 \mathrm{ml}$ pyridine,_(semi carbazide, thiosemicarbazide and phenylsemicarbazide) respectively $(0.01 \mathrm{~mole})$ were added and the reaction mixture was heated under reflux for (6-8hrs), and poured into cold diluted $\mathrm{HCl}$. the crud solid product that separated was filtered off, washed with water, dried and recrystallized from ethanol to give crystals. Physical properties of compounds [2-4] are listed in Table (1).

\subsubsection{Synthesis of 3-amino-2-pentadecylquinazolin-4(3H)-one ${ }^{(11)}$ [5]:}

Compound [1] (3.57gm, 0.01mole) in (10 ml) dimethylformamide (DMF) as solvent; excess of $99 \%$ hydrazine hydrate in ethanol $(30 \mathrm{ml})$ was added to the reaction mixture and reflexed for $(6 \mathrm{hrs}$.). Finally, the reaction mixture cooled to room temperature, poured on ice-cold water, stirred and filtered. The precipitate was recrystallized from ethanol to give off white crystals. Physical properties of compound [5] are listed in Table (1).

\subsubsection{Synthesis of N-(4-0xo-2-pentadecylquinazolin-3(4H)-yl) benzamide ${ }^{(12)}[6]$.}

Compound [5] (3.68 gm, 0.01 mole) in dry acetone $(40 \mathrm{ml})$ containing a catalytic amount of pyridine (3drops), $(1.2 \mathrm{ml}, 0.01 \mathrm{~mole})$ benzoyl chloride was added in drop wise maintaining the temperature near $8^{\circ} \mathrm{C}$ for $(1 \mathrm{hrs}$.). The reaction mixture was refluxed for another ( $3 \mathrm{hrs}$.), and then cooled at room temperature. The separated solid product was filtered off and recrystallized from ethanol. Physical properties of compound [6] are listed in Table (2).

2.1.5 Synthesis of N-(4-oxo-2-pentadecylquinazolin-3(4H)-yl) acetamide ${ }^{(12)}[7]$.

A solution of compound [5] (3.68 gm, 0.01 mole) in dry acetone $(40 \mathrm{ml})$ and acetyl chloride $(0.8 \mathrm{ml}$, $0.01 \mathrm{~mole})$ in pyridine $(20 \mathrm{ml})$ was refluxed for $(5 \mathrm{hrs}$.). The cold mixture was poured into ice/water. The separated solid was filtered off, dried and recrystallized from benzene-hexane. Physical properties of compound [7] are listed in Table (2).

\subsubsection{Synthesis of $\mathrm{N}$-(4-0xo-2-pentadecylquinazolin-3(4H)-yl)-2-chloro acetamide ${ }^{(14)}[8]$.}

A mixture of compound [5] (3.68 gm, $0.01 \mathrm{~mole})$ in dry acetone and chloroacetyl chloride $(0.8 \mathrm{ml}, 0.01$ mole) was refluxed for $6 \mathrm{hrs}$. The mixture was then poured into cold water $(30 \mathrm{ml})$ and the precipitated solid was filtered off, dried and recrystallized from benzene. Physical properties of compound [8] are listed in Table (2).

2.1.7 Synthesisof N-(4-oxo-2-pentadecylquinazoline-3(4H)-yl) carbothioamide[9], carboxamide ${ }^{(15)}[10]$. Compound [1] (3.57gm, $0.01 \mathrm{~mole})$ in $(15 \mathrm{ml})$ dimethylformamide (DMF) as solvent; was refluxed with $(0.8 \mathrm{gm}, 0.01 \mathrm{~mole})$ (thiourea and urea) respectively in $(40 \mathrm{ml})$ dry acetone containing a catalytic amount of pyridine (3drops), for (10hrs.). The reaction mixture cooled to room temperature, poured on ice-cooled water, the formed precipitate was filtered and recrystallized from ethanol. Physical properties of compounds [9] and [10] are listed in Table (3).

\subsubsection{Synthesis of 3-hydroxy-2-pentadecylquinazolin-4(3H)-one ${ }^{(16)}[11]$.}

A solution of compound [1] $(3.57 \mathrm{gm}, 0.01 \mathrm{~mole})$ in in $(20 \mathrm{ml})$ dimethylformamide (DMF) and hydroxylamine hydrochloride $(0.7 \mathrm{gm}, 0.01 \mathrm{~mole})$ in pyridine $(25 \mathrm{ml})$ was refluxed for $(16 \mathrm{hrs}$.). The reaction mixture was cooled and poured into a crushed ice water. The solid that separated was filtered off, washed with water, dried and then recrystallized from dioxane to give the required products. Physical properties of compound [11] are listed in Table (3).

\subsubsection{Synthesis of 2-(4-oxo-2-pentadecylquinazolin-3(4H)-yl)acetic acid ${ }^{(17)}[12]$.}

To a solution of compound [1] (3.57gm, 0.01 mole) in ( $25 \mathrm{ml})$ dimethylformamide (DMF), $(0.75 \mathrm{gm}$, 0.01 mole) glycine in dry pyridine $(20 \mathrm{ml})$ was added and the heated under reflux for ( $4 \mathrm{hrs}$.) then left to cool at room temperature. The reaction mixture was poured into ice $/ \mathrm{HCl}$ to reveal the solid product, which was filtered off, washed with water, dried and recrystallized from ethanol. Physical properties of compound [12] are listed in Table (3). 
2.1.10 Synthesis of 2-pentadecylquinazolin- $4(3 \mathrm{H}) \mathrm{one}^{(18)}[13]$.

compound [1] (3.57gm, 0.01 mole) was fused with of ammonium acetate (3gm, 0.04mole) heated in an oil bath in temperature $(160-170){ }^{\circ} \mathrm{C}$ for $(2 \mathrm{hrs}$.), then cooled, water is added, the solid product obtained after filtration and recrystallized from methanol. Physical properties of compound [13] are listed in Table (3).

2.1.11 Synthesis of 2-pentadecyl-3-(phenylamino)quinazolin-4(3H)-one ${ }^{(19)}[14]$.

Compound [1] $(3.57 \mathrm{gm}, 0.01 \mathrm{~mole})$ and phenyl hydrazine $(1.08 \mathrm{gm}, 0.01 \mathrm{~mole})$ were dissolved in absolute ethanol $(50 \mathrm{ml})$. This solution was refluxed for $(12 \mathrm{hrs}$.$) . Concentrated, cooled and poured into crushed$ ice and filtered. The solid thus obtained was purified by recrystallization from ethanol. Physical properties of compound [14] are listed in Table (3).

\subsection{Conversion of the prepared compounds to nonionic surfactants ${ }^{(20)}$ :}

They are prepared by the addition of (n) moles of propylene oxide $(n=3,5,7)$ to one mole of synthesized compounds $(2,4,5,7$ and 12$)$ by mixed with $\mathrm{KOH}(0.1 \mathrm{wt} \%)$ The mixture was heated up to $130^{\circ} \mathrm{C}$ and a rapid stream of $\mathrm{N}_{2}$ gas was passed continuously for about $20 \mathrm{~min}$ to exclude the oxygen and water vapors. And the product was characterized by FT-IR spectrophotometer. The addition of propylene oxide gave a mixture of propenoxylated products whose structures were shown through IR spectra to be two broad bands at 1100 and $950 \mathrm{~cm}^{-1}$ and by ${ }^{1} \mathrm{HNMR}$ spectra showed $\delta=(3.2-3.7) \mathrm{ppm}$.

\subsection{Determination of the performance properties}

1. Surface and interfacial tensions:

Surface and interfacial tensions were measured with a Du-Nouy tensiometer (Kruss, Type 8451) using an aqueous solution of surfactants $(0.1 \mathrm{wt} \%)$ at room temperature $\left(25^{\circ} \mathrm{C}\right)^{(21)}$.

\section{Cloud point:}

Cloud point was determined by gradually heating a surfactant solution $(1.0 \mathrm{wt} \%)$ in a temperature controlled bath, and recording the temperature at which the clear, or nearly clear solutions become definitely turbid. The reproducibility of this temperature was checked by cooling the solutions until they became clear again ${ }^{(21)}$.

\section{Wetting time:}

Wetting time was determined by immersing a sample of cotton fabric in a $(1.0 \mathrm{wt} \%)$ aqueous solution of surfactants ${ }^{(21)}$.

\section{Foaming properties:}

Foaming properties were measured according to El-Sukkary et al (1987). In this procedure a $25 \mathrm{ml}$ solution (1.0 wt \%) was shaken vigorously for 10 seconds in a $100 \mathrm{ml}$ graduated cylinder with glass stopper at $25^{\circ} \mathrm{C}$. The solution was allowed to stand for 30 seconds, and then, the foam height was measured ${ }^{(22)}$.

\section{Emulsification stability:}

Emulsification stability was prepared from $10 \mathrm{ml}$ of a $20 \mathrm{mmol}$ aqueous solution of surfactant and $5 \mathrm{ml}$ of toluene at $40{ }^{\circ} \mathrm{C}$. Emulsion stability was determined as the time it took $9 \mathrm{ml}$ of an aqueous layer to separate from the emulsion once shaking had stopped ${ }^{(23)}$.

\section{Determination of CMC of Surfactant by Surface Tension Method:}

Surface tension measurements were done by applying du Nouy ring method using Du-Nouy (Kruss, Type 8451) tensiometer and platinum ring at room temperature $\left(25^{\circ} \mathrm{C}\right)$. Stock solution of $5 \%(\mathrm{v} / \mathrm{v})$ of synthesized nonionic surfactant in aqua was prepared in $1 \mathrm{~L}$ volumetric flask. First of all, the surface tension of pure water in a glass vessel was noted. The surface tensions were measured by a dilution method in which a $5 \%$ $(\mathrm{v} / \mathrm{v})$ of synthesized nonionic surfactant stock solution was gradually diluted by deionized water. After each dilution the solution was stirred for $30 \mathrm{~s}$, and then left for $2 \mathrm{~min}$ before reading the surface tension value. All surface tension measurements were done at least three times or up to obtaining repeated value. The CMC values were determined by plotting surface tension versus concentrations of surfactant ${ }^{(23)}$.

Table (1) : Physical properties and FT-IR spectral data $\mathrm{cm}^{-1}$ of the synthesized compounds (1-5).

\begin{tabular}{|l|l|l|l|l|l|l|l|l|l|}
\hline \multirow{2}{*}{$\begin{array}{l}\text { Com. } \\
\text { No. }\end{array}$} & Physical Properties & Structures & $\begin{array}{l}\text { M.P } \\
{ }^{\circ} \mathrm{C}\end{array}$ & $\begin{array}{l}\text { Yield } \\
\%\end{array}$ & Color & $\begin{array}{l}v(\mathrm{C}-\mathrm{H}) \\
\text { arom. }\end{array}$ & $\begin{array}{l}v(\mathrm{C}-\mathrm{H}) \\
\text { aliph. }\end{array}$ & $\begin{array}{l}v(\mathrm{C}=\mathrm{O}) \\
\begin{array}{l}v(\mathrm{C}=\mathrm{C}) \\
\text { aromati } \\
\mathrm{c}\end{array}\end{array}$ & Others \\
\hline 1 & & $48-50$ & 75 & $\begin{array}{l}\text { Pale } \\
\text { yellow }\end{array}$ & 3030 & $\begin{array}{l}2920 \\
2850\end{array}$ & 1764 & $\begin{array}{l}1598 \\
1533 \\
1487\end{array}$ & $\begin{array}{l}v(\mathrm{C}=\mathrm{N}) \\
1641\end{array}$ \\
\end{tabular}


Synthesis, Identification And Surface Active Properties Of Some Nonionic Surfactants Containing

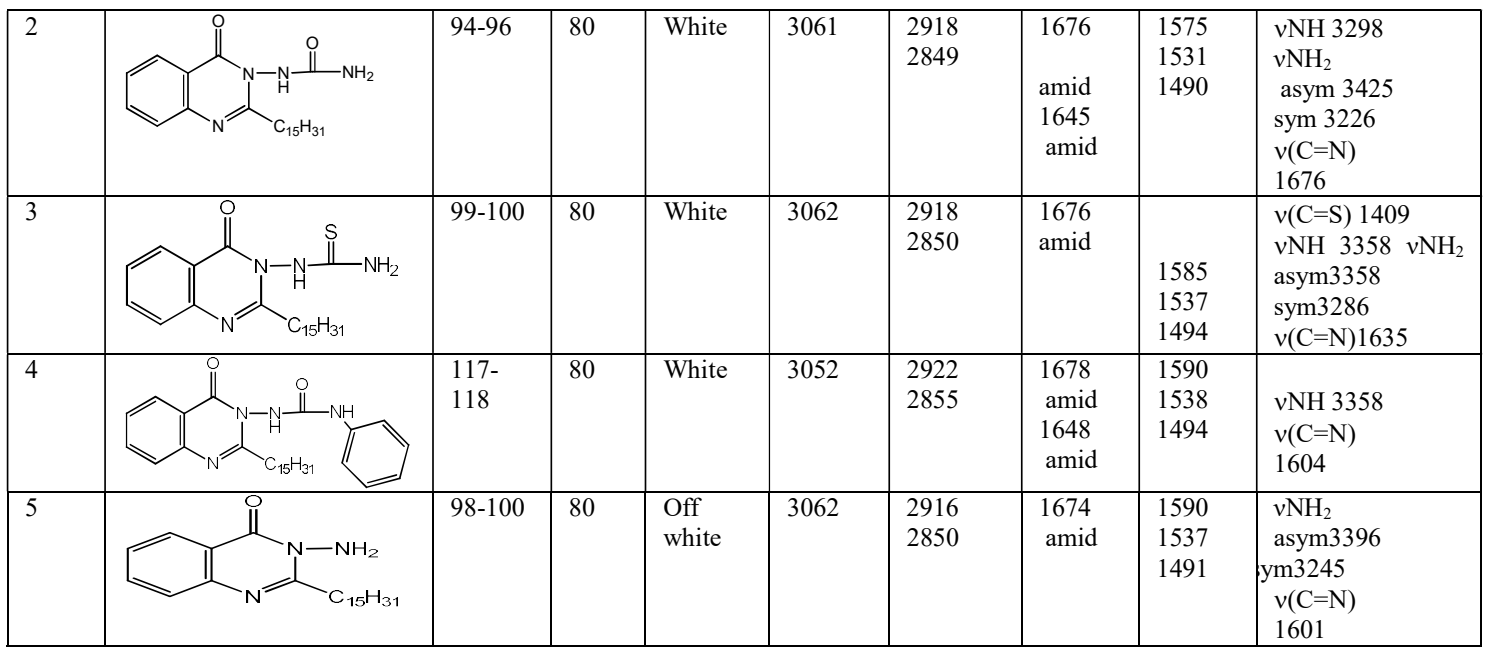

Table (2) : Physical properties and FT-IR spectral data $\mathrm{cm}^{-1}$ of the synthesized compounds (6-8).

\begin{tabular}{|c|c|c|c|c|c|c|c|c|c|}
\hline \multirow{2}{*}{$\begin{array}{l}\text { Com. } \\
\text { No. }\end{array}$} & \multicolumn{4}{|c|}{ Physical Properties } & \multicolumn{5}{|c|}{ Major FT-IR Absorption $\mathrm{cm}^{-1}$} \\
\hline & Structures & $\begin{array}{l}\text { M.P } \\
{ }^{\circ} \mathrm{C}\end{array}$ & $\begin{array}{l}\text { Yield } \\
\%\end{array}$ & Color & $\begin{array}{l}v(\mathrm{C}-\mathrm{H}) \\
\text { arom. }\end{array}$ & $\begin{array}{l}v(\mathrm{C}-\mathrm{H}) \\
\text { aliph. }\end{array}$ & $v(\mathrm{C}=\mathrm{O})$ & $\begin{array}{l}v(\mathrm{C}=\mathrm{C}) \\
\text { aromatic }\end{array}$ & Others \\
\hline 6 & & $88-90$ & 85 & White & 3030 & $\begin{array}{l}2910 \\
2850\end{array}$ & $\begin{array}{l}1689 \\
\text { amid }\end{array}$ & $\begin{array}{l}1580 \\
1540 \\
1492\end{array}$ & $\begin{array}{l}v \mathrm{NH} 3329 \\
v(\mathrm{C}=\mathrm{N}) \\
1604\end{array}$ \\
\hline 7 & & $\begin{array}{l}102- \\
104\end{array}$ & 85 & White & 3035 & $\begin{array}{l}2911 \\
2849\end{array}$ & $\begin{array}{l}1697 \\
\text { amid }\end{array}$ & $\begin{array}{l}1585 \\
1541 \\
1488\end{array}$ & $\begin{array}{l}v \mathrm{NH} 3329 \\
v(\mathrm{C}=\mathrm{N}) \\
1608\end{array}$ \\
\hline 8 & & $\begin{array}{l}104- \\
106\end{array}$ & 85 & $\begin{array}{l}\text { Off } \\
\text { white }\end{array}$ & 3030 & $\begin{array}{l}2910 \\
2850\end{array}$ & $\begin{array}{l}\begin{array}{l}1685 \\
\text { amid }\end{array} \\
1705 \\
\text { amid }\end{array}$ & $\begin{array}{l}1585 \\
1555 \\
1490\end{array}$ & $\begin{array}{l}v N H 3329 \\
v(\mathrm{C}=\mathrm{N}) \\
1635\end{array}$ \\
\hline
\end{tabular}

Table (3) : Physical properties and FT-IR spectral data $\mathrm{cm}^{-1}$ of the synthesized compounds (9-14).

\begin{tabular}{|c|c|c|c|c|c|c|c|c|c|}
\hline \multirow{2}{*}{$\begin{array}{l}\text { Com. } \\
\text { No. }\end{array}$} & \multicolumn{4}{|c|}{ Physical Properties } & \multicolumn{5}{|c|}{ Major FT-IR Absorption $\mathrm{cm}^{-1}$} \\
\hline & Structures & $\begin{array}{l}\text { M.P } \\
{ }^{\circ} \mathrm{C}\end{array}$ & $\begin{array}{l}\begin{array}{l}\text { Yield } \\
\%\end{array} \\
\end{array}$ & Color & $\begin{array}{l}v(\mathrm{C}-\mathrm{H}) \\
\text { arom. }\end{array}$ & $\begin{array}{l}v(\mathrm{C}-\mathrm{H}) \\
\text { aliph. }\end{array}$ & $v(\mathrm{C}=\mathrm{O})$ & $\begin{array}{l}v(\mathrm{C}=\mathrm{C}) \\
\text { aromatic }\end{array}$ & Others \\
\hline 9 & & $90-91$ & 75 & White & 3040 & $\begin{array}{l}2920 \\
2860\end{array}$ & $\begin{array}{l}1677 \\
\text { amid }\end{array}$ & $\begin{array}{l}1600 \\
1565 \\
1494\end{array}$ & $\begin{array}{c}v \mathrm{NH} 2 \\
3440,3336 \\
v(\mathrm{C}=\mathrm{S}) \\
1413.7 \\
v(\mathrm{C}=\mathrm{N}) \\
1606.5\end{array}$ \\
\hline 10 & & $88-90$ & 75 & White & 3040 & $\begin{array}{l}2960 \\
2860\end{array}$ & $\begin{array}{c}1699 \\
\text { amid } \\
1677 \\
\text { amid }\end{array}$ & $\begin{array}{l}1585 \\
1555 \\
1490\end{array}$ & $\begin{array}{c}v \mathrm{NH} 2 \\
3421,3320 \\
v(\mathrm{C}=\mathrm{N}) \\
1608\end{array}$ \\
\hline 11 & & $72-73$ & 70 & $\begin{array}{l}\text { off } \\
\text { White }\end{array}$ & 3067 & $\begin{array}{l}2920- \\
2850\end{array}$ & $\begin{array}{l}1685 \\
\text { amid }\end{array}$ & $\begin{array}{l}1605 \\
1550 \\
1492\end{array}$ & $\begin{array}{c}\mathrm{vOH} 3420 \\
v(\mathrm{C}=\mathrm{N}) \\
1604\end{array}$ \\
\hline 12 & & $92-93$ & 75 & White & 3060 & $\begin{array}{l}2945 \\
2850\end{array}$ & $\begin{array}{l}1732 \\
\text { acid } \\
1697 \\
\text { amid }\end{array}$ & $\begin{array}{l}1595 \\
1565 \\
1490\end{array}$ & $\begin{array}{c}\mathrm{vOH} 3340 \\
v(\mathrm{C}=\mathrm{N}) \\
1608\end{array}$ \\
\hline 13 & & $\begin{array}{l}114 \\
115\end{array}$ & 70 & White & 3036 & $\begin{array}{l}2920- \\
2850\end{array}$ & $\begin{array}{l}1681 \\
\text { amid }\end{array}$ & $\begin{array}{l}1605 \\
1550 \\
1492\end{array}$ & $\begin{array}{c}v \mathrm{NH} 3168 \\
v(\mathrm{C}=\mathrm{N}) \\
1604\end{array}$ \\
\hline
\end{tabular}


Synthesis, Identification And Surface Active Properties Of Some Nonionic Surfactants Containing

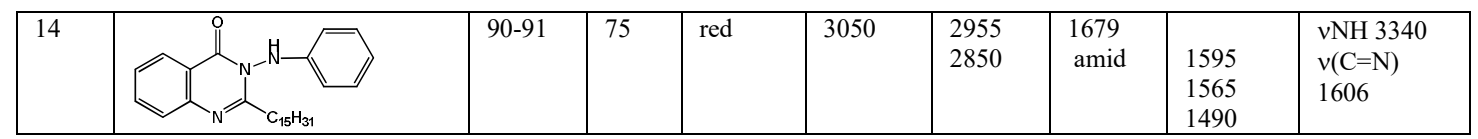

\section{Results And Discussion}

The synthetic sequences for preparation of series new 2-pentadecyl quinazolinone compounds by reaction of pentadecanoyl chloride with anthranilic acid gave 2-pentadecyl-4H-benzo[3,1]oxazin-4-one [1] which was used as starting material to synthesis some quinazolinone compounds by a reaction with nitrogen nucleophiles (e.g., semicarbazide, thiosemicrabazide, phenylsemicarbazide and hydrazine hydrate) are show in scheme(1).

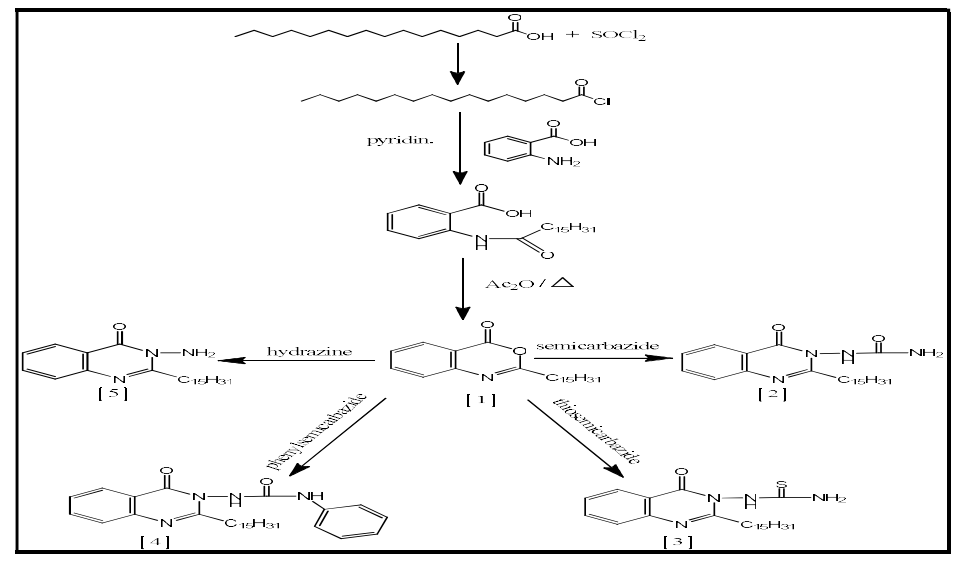

Scheme (1): Synthesis of new derivatives of quinazolinone (1-5)

Physical properties of compounds [2, 3, 4 and 5] are listed in Table (1). FTIR spectrum of prepared compounds [2, 3, 4 and 5] showed appearance of absorptions at (3425-3396) $\mathrm{cm}^{-1}$ and at (3286-3226) $\mathrm{cm}^{-1}$ of $v \mathrm{NH}_{2}$ asym. and sym. respectively. $(3358,3298) \mathrm{cm}^{-1}$ of $v \mathrm{NH}$ group, Also it showed shift in the $v \mathrm{C}=\mathrm{O}$ band from $\left(1764 \mathrm{~cm}^{-1}\right)$ of cyclic ester to $\left(1690-1645 \mathrm{~cm}^{-1}\right)$ of amide. FTIR spectral data are listed in Table (1). ${ }^{1} \mathrm{H}-$ NMR spectrum of compound [3] showed triplet signal at $\delta=(0.85) \mathrm{ppm}$ due to $\left(-\mathrm{CH}_{3}\right)$ protons, multiplet signal at $\delta=(1.2-2.66)$ ppm due to $(\mathrm{C}-\mathrm{H})$ protons of long chain $14 \mathrm{CH}_{2}$, signals at $\delta=(7.11-7.60)$ ppm due to aromatic rings protons, singlet signal at $\delta=(8.09-8.51) \mathrm{ppm}$ due to $\left(-\mathrm{NH}_{2}\right)$ protons, and singlet signal at $\delta=(11.1) \mathrm{ppm}$ due to $(\mathrm{N}-\mathrm{H})$ proton as shown in Table (4). ${ }^{13} \mathrm{C}-\mathrm{NMR}$ spectrum of compound [3] showed signals at $\delta=(22-27)$ ppm, $\delta=(122-133) \mathrm{ppm}, \delta=(147) \mathrm{ppm}, \delta=(162.29) \mathrm{ppm}$ and $\delta=(174.5) \mathrm{ppm}$ belong to long chain $\left(\mathrm{C}_{15} \mathrm{H}_{31}\right),(\mathrm{C}-$ aromatic), $(\mathrm{C}=\mathrm{N})$ imine, $(\mathrm{C}=\mathrm{O})$ ester and $(\mathrm{C}=\mathrm{S})$ respectively. ${ }^{13} \mathrm{CNMR}$ spectral data of compound [3] is listed in Table (5).

Table (4) ${ }^{1} \mathrm{H}-\mathrm{NMR}$ spectral data (ppm) for selected compounds.

\begin{tabular}{|l|l|l|}
\hline $\begin{array}{l}\text { Comp. } \\
\text { No. }\end{array}$ & Structures \\
\hline 1
\end{tabular}


Synthesis, Identification And Surface Active Properties Of Some Nonionic Surfactants Containing

\begin{tabular}{|l|l|l|}
\hline 9 & $\begin{array}{l}\delta 0.85\left(\mathrm{t}, 3 \mathrm{H}, \mathrm{CH}_{3}\right), \delta 1.8-2.38\left(\mathrm{~m}, 28 \mathrm{H}, 14 \mathrm{CH}_{2}\right), \delta 7.11-7.9(\mathrm{~m}, 4 \mathrm{H}, \mathrm{ArH}), \delta 8.5- \\
9.14\left(\mathrm{~s}, 2 \mathrm{H}, \mathrm{NH}_{2}\right)\end{array}$ \\
\hline
\end{tabular}

Table (5) : ${ }^{13} \mathrm{C}-\mathrm{NMR}$ spectral data (ppm) for selected compounds.

\begin{tabular}{|l|l|l|}
\hline $\begin{array}{l}\text { Com. } \\
\text { No }\end{array}$ & $\begin{array}{l}22-27 \quad\left(\text { Long chain } \mathrm{C}_{7}\right) ; 122\left(\mathrm{C}_{1}\right) ; 127\left(\mathrm{C}_{2}\right) 134\left(\mathrm{C}_{4}\right), 147\left(\mathrm{C}_{3}\right) ; 148\left(\mathrm{C}_{6}\right) ; \\
162.4\left(\mathrm{C}_{5}\right) .\end{array}$ \\
\hline 1
\end{tabular}

Compound [5] allowed to react with halogenated compounds such as benzoyl chloride, acetyl chloride and chloro acetyl chloride by nucleophilic substitution reaction to synthesis newly derivatives of quinazolinone compounds [6], [7] and [8]. This reaction carried out in presence of catalytic amount of pyridine and DMF. The synthetic sequences for preparation of new N-(4-oxo-2-pentadecylquinazolin-3(4H)-yl) benzamide [6], acetamide [7] and chloro acetamide [8] was performed as outlined in scheme (2).

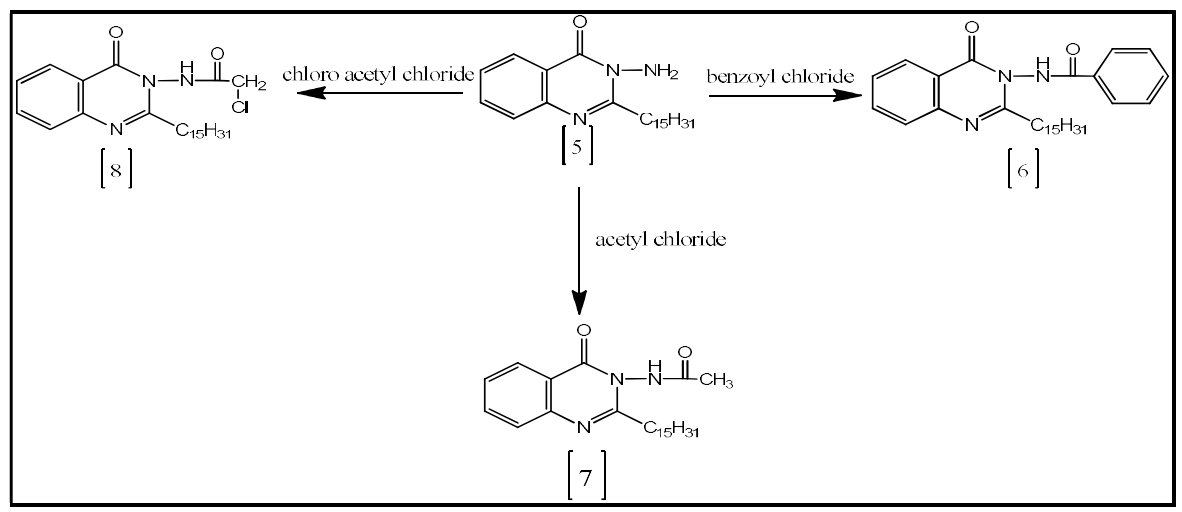

Scheme (2)

Physical properties of compounds [6], [7] and [8] listed in Table (2). FTIR spectrum of compound [6], [7] and [8] showed disappearance of $v\left(\mathrm{NH}_{2}\right)$ absorption band at 3496 and $3245 \mathrm{~cm}^{-1}$ and appearance of characteristic absorption bands at $v \mathrm{~cm}^{-1} 3329$ for $v(\mathrm{~N}-\mathrm{H}), 3030$ for C-H aromatic; 2910 and 2850 for C-H aliph 
; 1689 for $\mathrm{C}=\mathrm{O}$ (amide) ; 1604 for $\mathrm{C}=\mathrm{N}$ of compound[6]; 1697 for $\mathrm{C}=\mathrm{O}$ (amid) of compound[7]; and 1685for $\mathrm{C}=\mathrm{O}$ (amide) of compound[8]; $\mathrm{vC}=\mathrm{N}(1604-1635) \mathrm{cm}^{-1} .{ }^{1} \mathrm{H}-\mathrm{NMR}$ spectrum data of compound [6] showed triplet signal at $\delta=(0.84) \mathrm{ppm}$ due to $\left(-\mathrm{CH}_{3}\right)$ protons, multiplet signal at $\delta=(1.22-2.50) \mathrm{ppm}$ due to $(\mathrm{C}-\mathrm{H})$ protons of long chain $14 \mathrm{CH}_{2}$, signals at $\delta=(6.51-7.84) \mathrm{ppm}$ due to aromatic rings protons, singlet signal at $\delta=$ (9.10) ppm due to $(\mathrm{N}-\mathrm{H})$ proton. ${ }^{1} \mathrm{H}-\mathrm{NMR}$ Spectral data of compounds [6] are listed in Table (4). ${ }^{13} \mathrm{C}-\mathrm{NMR}$ spectrum of compound [6] showed signals at $\delta=(22-27) \mathrm{ppm}, \delta=(126-135) \mathrm{ppm}, \delta=(146) \mathrm{ppm}$ and $\delta=(168)$ ppm belong to long chain $\left(\mathrm{C}_{15} \mathrm{H}_{31}\right),(\mathrm{C}$-aromatic $),(\mathrm{C}=\mathrm{N})$ imine and $(\mathrm{C}=\mathrm{O})$ ester respectively. ${ }^{13} \mathrm{CNMR}$ spectral data of compound [6] are listed in Table (5). While ${ }^{1} \mathrm{H}-\mathrm{NMR}$ spectrum data of compound [7] showed triplet signal at $\delta=(0.83) \mathrm{ppm}$ due to $\left(-\mathrm{CH}_{3}\right)$ protons, multiplet signal at $\delta=(1.27-2.4)$ ppm due to $(\mathrm{C}-\mathrm{H})$ protons of long chain $14 \mathrm{CH}_{2}$, singlet signal at $\delta=(3.47) \mathrm{ppm}$ due to $\left(\mathrm{O}=\mathrm{C}-\mathrm{CH}_{3}\right)$ proton, signals at $\delta=(7.01-8.51)$ ppm due to aromatic rings protons. ${ }^{1} \mathrm{H}-\mathrm{NMR}$ Spectral data of compounds [7] are listed in Table (4). ${ }^{13} \mathrm{C}-\mathrm{NMR}$ spectrum of compound [7] showed signals at $\delta=(22-27) \mathrm{ppm}, \delta=58 \mathrm{ppm}, \delta=(128-134) \mathrm{ppm}, \delta=(145) \mathrm{ppm}, \delta=(154)$ ppm, $\delta=(161)$ ppm and $\delta=(169)$ ppm belong to long chain $\left(\underline{\mathrm{C}}_{15} \mathrm{H}_{31}\right),\left(\mathrm{O}=\mathrm{C}-\mathrm{CH}_{3}\right),(\mathrm{C}-$ aromatic $),(\underline{\mathrm{C}}=\mathrm{N})$ imine , $(\underline{\mathrm{C}}=\mathrm{O})$ ester $\left(\underline{\mathrm{C}}=\mathrm{O}-\mathrm{CH}_{3}\right)$ respectively. ${ }^{13} \mathrm{CNMR}$ spectral data of compound [7] are listed in Table $(5)$. The syntheses of different new quinazolinone compounds by reaction of compound [1] with different substituted amine compounds. These different synthesized compounds that are presented in Scheme (3).

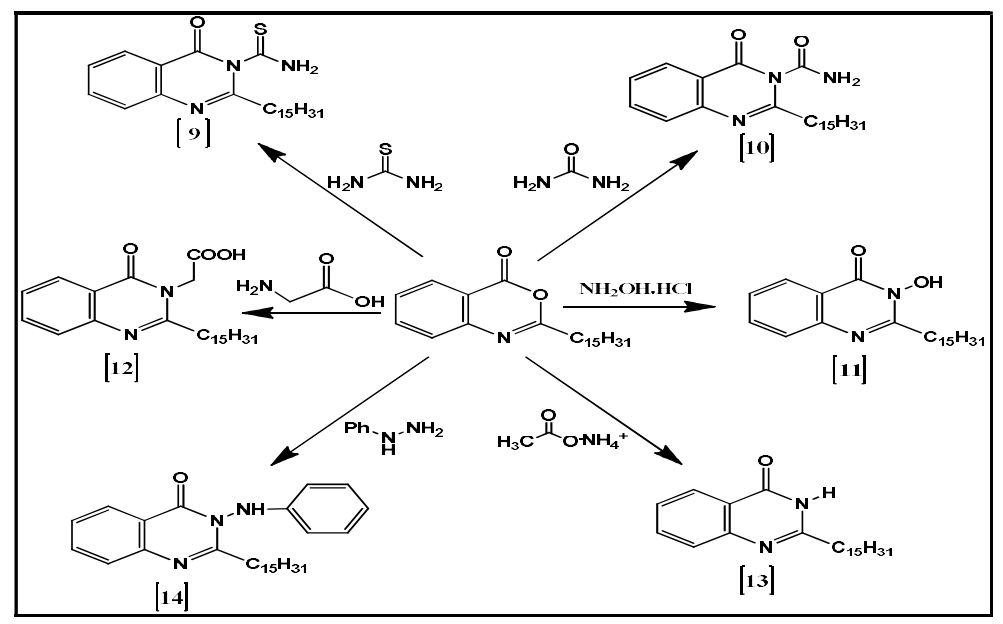

Scheme (3)

Reaction of compound [1] with thiourea and urea in presence catalytic amount of pyridine afforded the product N-(4-oxo-2-pentadecylquinazoline-3(4H)-yl) carbothioamide [9], carboxamide [10] respectively. Physical properties of compounds [9] and [10] are listed in Table (3). FTIR spectrum of prepared compounds [9-10] showed appearance of absorptions at $(3440-3320) \mathrm{cm}^{-1},(3040) \mathrm{cm}^{-1},(2960,2860) \mathrm{cm}^{-1},(1699$ and 1677) $\mathrm{cm}^{-1},(1608) \mathrm{cm}^{-1}$ due to $v-\mathrm{NH}_{2}, v \mathrm{C}-\mathrm{H}$ aromatic, $v \mathrm{C}-\mathrm{H}$ aliphatic, $v \mathrm{C}=\mathrm{O}$ for amide, $v \mathrm{C}=\mathrm{N}$ of compounds (9 and 10), in addition (1413) $\mathrm{cm}^{-1}$ for $v \mathrm{C}=\mathrm{S}$ of compound [9]. In the other hand ${ }^{1} \mathrm{HNMR}$ spectra data of compound (9) $\delta$ ppm in DMSO-d $\mathrm{d}_{6}$ solvent showed singlet signal at $\delta=(0.85) \mathrm{ppm}$ due to $\left(-\mathrm{CH}_{3}\right)$ protons, multiplate signale at $\delta=(1.18-2.38)$ due to long chain $\left(14 \mathrm{CH}_{2}\right)$, signals at $\delta=(7.9-7.11)$ ppm due to aromatic ring protons and $\delta=(8.5-9.14) \mathrm{ppm}$ due to $\left(-\mathrm{NH}_{2}\right)$ protons. As listed in table (4). ${ }^{13} \mathrm{C}-\mathrm{NMR}$ spectrum data of compound [9] showed signals at $\delta=(17-27) \mathrm{ppm}, \delta=(121-134) \mathrm{ppm}, \delta=(148) \mathrm{ppm}, \delta=(164.07) \mathrm{ppm}$ and $\delta=$ (182.3) ppm belong to long chain $\left(-\mathrm{C}_{15} \mathrm{H}_{31}\right), \quad(\mathrm{C}$-aromatic $), \quad(\mathrm{C}=\mathrm{N}), \quad(\mathrm{C}=\mathrm{O})$ amide and $(\mathrm{C}=\mathrm{S})$ respectively. ${ }^{13} \mathrm{CNMR}$ spectral data of compound [9] is listed in Table (5).. the synthesized quinazolinone derivatives bearing an active hydrogen atom such as $\left(-\mathrm{NH},-\mathrm{OH},-\mathrm{COOH}\right.$ and $\left.-\mathrm{NH}_{2}\right)$ and the structure of a surface active agent requires a hydrophilic component. This is accomplished through the condensation of propylene oxide with different moles, $(3,5$ and 7$)$ moles in the presence of $\mathrm{KOH}$ as catalyst at any active hydrogen atom of synthesized compounds [2, 4, 5, 7 and 12] which contain one or more active hydrogen atoms to yield novel groups of nonionic surfactant (2(a-c), 4(a-c), 5(a-c), 7(a-c) and 12(a-c)) respectively that showed in scheme (4). 


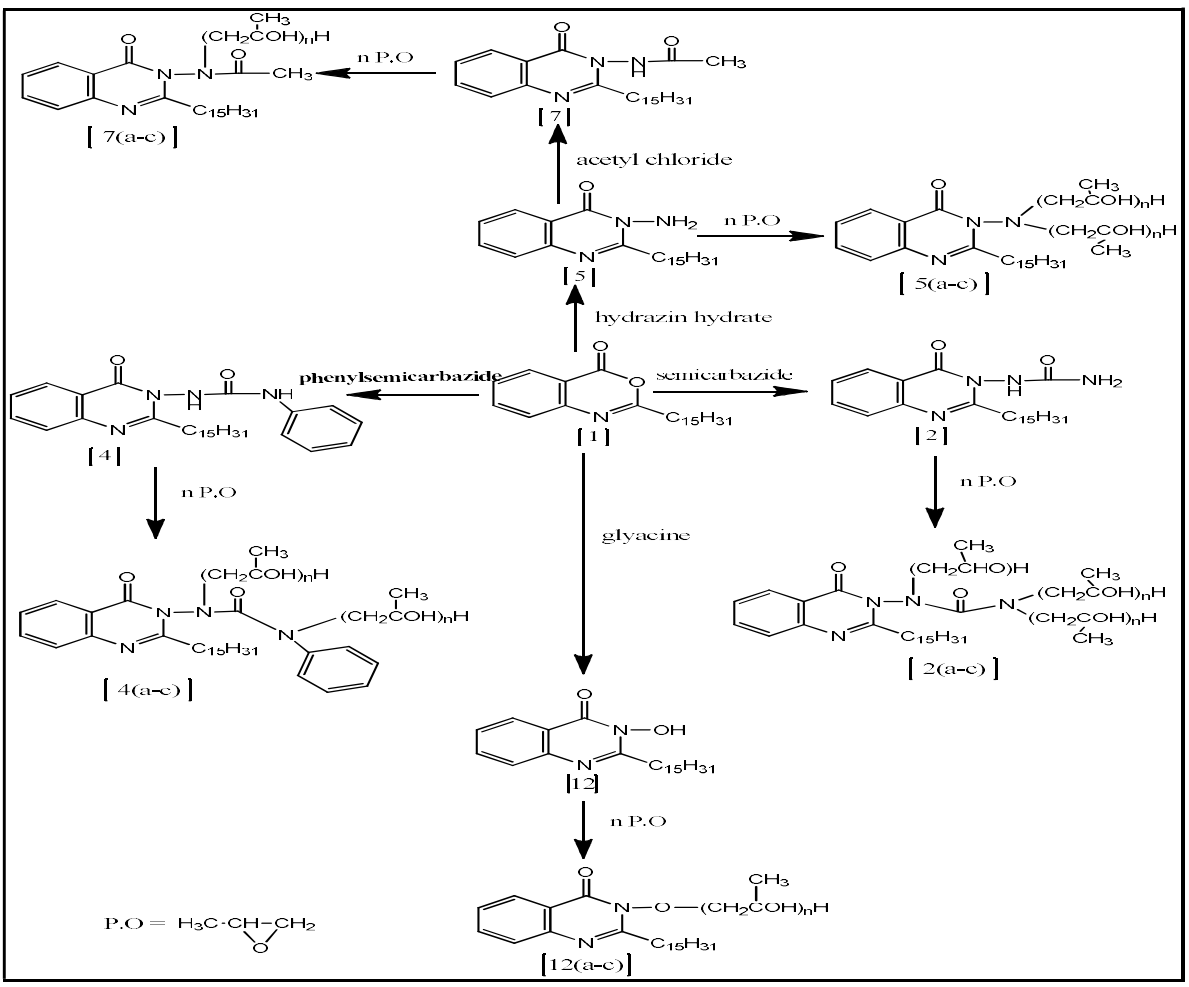

Scheme (4)

The study of the surface active properties of the polypropenoxy compounds has been done in an aqueous solution $(1 \mathrm{wt} \%, \mathrm{pH}=7)$ at $25^{\circ} \mathrm{C}$. The surface activity and related properties of the synthesized compounds including surface tension and interfacial tension, wetting time, cloud point, foaming height, emulsification properties and CMC are given in Table (6).

The surface and interfacial tension of the synthesized compounds are shown in Table (6). It can be observed that the nonionic surfactants have pronounced surface activity. The surface and interfacial tension increase with an increase in the molecular weight of the hydrophobic moiety. The data given in Table (6) shows that the values of surface and interfacial tension increased with the increase in the number of propylene oxide units added to the molecule. ${ }^{(24)}$

A very important factor in making the most efficient use of nonionic surfactants in an aqueous system is an understanding of the property called cloud point. All synthesized compounds showed high cloud points which gave performance in hot water and it was increased by increasing the number of the propoxy group.

All the synthesized compounds showed a decrease in wetting time with an increase in the number of propylene oxide units in the molecule. Moreover, the presence of propylene oxide in different moles caused a reduction in wetting time, i.e. improving their wetting properties which make widely applicable in the textile industry. ${ }^{(25)}$

Nonionic surfactants containing an aromatic ring such showed poor foaming properties. The foam height of the prepared surfactants increases with an increase in the number of propylene oxide units per molecule of surfactant. The low foaming power could have an application in the dyeing auxiliary industry

Emulsification is one of the most important Properties of surfactants. In many textile processes such as scouring and dyeing, it is necessary to introduce surfactants into the bath to remove oily impurities from the fibers. On the other hand, nonionic surfactants with good emulsion stability have been used in such fields as, shampoos, cosmetics, emulsion paints and the textile industry. The results in Table (6) showed that the emulsion stability increases by decreasing the number of propylene oxide units. 
Synthesis, Identification And Surface Active Properties Of Some Nonionic Surfactants Containing

Table (6) surface properties of synthesized compounds (2(a-c), 4(a-c), 5(a-c), 7(a-c) and 12(a-c))

\begin{tabular}{|c|c|c|c|c|c|c|c|c|}
\hline compd & $\begin{array}{l}\text { No of } \\
\text { moles }\end{array}$ & $\begin{array}{l}\text { Surface } \\
\text { Tension } \\
(\text { dyne/cm) } \\
0.1 w t \%\end{array}$ & $\begin{array}{l}\text { Interfacial } \\
\text { tension } \\
\text { (dyne/cm) } \\
0.1 w t \%\end{array}$ & $\begin{array}{l}\text { Cloud point } \\
\text { C } \\
0.1 w t \%\end{array}$ & $\begin{array}{l}\text { Wetting } \\
\text { time }(\mathrm{Sec}) \\
0.1 \mathrm{wt} \%\end{array}$ & $\begin{array}{l}\text { Emulsion } \\
\text { stability (Min) } \\
25 \text { mmole }\end{array}$ & $\begin{array}{l}\text { Foam height } \\
(\mathrm{mm}) \\
0.1 \mathrm{wt} \%\end{array}$ & $\mathrm{CMC} \times 10^{-3}$ \\
\hline $2(a-c)$ & $\begin{array}{l}3 \\
5 \\
7\end{array}$ & $\begin{array}{l}32 \\
33 \\
35\end{array}$ & $\begin{array}{l}10 \\
11 \\
13\end{array}$ & $\begin{array}{l}58 \\
64 \\
73\end{array}$ & $\begin{array}{l}43 \\
32 \\
21\end{array}$ & $\begin{array}{l}92 \\
85 \\
74\end{array}$ & $\begin{array}{l}85 \\
115 \\
135\end{array}$ & $\begin{array}{l}3.6 \\
4.1 \\
4.3\end{array}$ \\
\hline $4(a-c)$ & $\begin{array}{l}3 \\
5 \\
7\end{array}$ & $\begin{array}{l}30 \\
33 \\
34\end{array}$ & $\begin{array}{l}9 \\
11 \\
12\end{array}$ & $\begin{array}{l}67 \\
75 \\
84\end{array}$ & $\begin{array}{l}46 \\
28 \\
20\end{array}$ & $\begin{array}{l}94 \\
84 \\
71\end{array}$ & $\begin{array}{l}90 \\
105 \\
130\end{array}$ & $\begin{array}{l}3.8 \\
4.0 \\
4.2\end{array}$ \\
\hline $5(a-c)$ & $\begin{array}{l}3 \\
5 \\
7\end{array}$ & $\begin{array}{l}28 \\
30 \\
32 \\
\end{array}$ & $\begin{array}{l}8 \\
10 \\
12 \\
\end{array}$ & $\begin{array}{l}74 \\
91 \\
98\end{array}$ & $\begin{array}{l}41 \\
33 \\
24 \\
\end{array}$ & $\begin{array}{l}101 \\
95 \\
75\end{array}$ & $\begin{array}{l}95 \\
110 \\
140 \\
\end{array}$ & $\begin{array}{l}3.9 \\
4.1 \\
4.3 \\
\end{array}$ \\
\hline $7(a-c)$ & $\begin{array}{l}3 \\
5 \\
7\end{array}$ & $\begin{array}{l}32 \\
33 \\
35\end{array}$ & $\begin{array}{l}9 \\
11 \\
13\end{array}$ & $\begin{array}{l}68 \\
82 \\
91\end{array}$ & $\begin{array}{l}49 \\
35 \\
26\end{array}$ & $\begin{array}{l}96 \\
85 \\
78\end{array}$ & $\begin{array}{l}105 \\
135 \\
150\end{array}$ & $\begin{array}{l}4.0 \\
4.1 \\
4.4\end{array}$ \\
\hline $12(a-c)$ & $\begin{array}{l}3 \\
5 \\
7\end{array}$ & $\begin{array}{l}33 \\
34 \\
35\end{array}$ & $\begin{array}{l}10 \\
13 \\
14\end{array}$ & $\begin{array}{l}72 \\
76 \\
81\end{array}$ & $\begin{array}{l}40 \\
31 \\
21\end{array}$ & $\begin{array}{l}112 \\
93 \\
87\end{array}$ & $\begin{array}{l}95 \\
120 \\
135\end{array}$ & $\begin{array}{l}3.4 \\
3.6 \\
3.9\end{array}$ \\
\hline
\end{tabular}

The reaction condition of propenoxilated compounds are illustrated in table (7).

Table (7) reaction condition of propenoxilated compounds

\begin{tabular}{|c|c|c|c|c|c|c|}
\hline compd & Catalyst,wt $\%$ & Temp C & Propenoxylated compounds & Yield $\%$ & $\begin{array}{l}\text { Degree of } \\
\text { propenoxylation }\end{array}$ & color \\
\hline 4 & \multirow{3}{*}{$\mathrm{KOH}, 0.01 \mathrm{wt} \%$} & \multirow{3}{*}{130} & $4(a-c)$ & $60-65$ & \multirow{3}{*}{3,5 and 7} & Pale brown cream \\
\hline 7 & & & $7(a-c)$ & $63-68$ & & Pale brown cream \\
\hline 12 & & & $12(a-c)$ & $72-75$ & & $\begin{array}{l}\text { Yellow white } \\
\text { Cream }\end{array}$ \\
\hline
\end{tabular}

${ }^{1} \mathrm{H}-\mathrm{NMR}$ spectra data of compound [4(a-c) and 5(a-c)] showed disappearance peaks $-\mathrm{NH}$ of compound [4] and $-\mathrm{NH}_{2}$ of compound [5]. And appearance multiplate signal at $\delta=(3.2-3.7) \mathrm{ppm}$ due to the protons of propenoxy groups $\left(-\mathrm{CH}_{2}-\mathrm{CH}-\left(\mathrm{CH}_{3}\right)-\mathrm{O}\right)$ - beside other characteristic bands as listed in table (8) and shown in Figure (1 and 2).

Table (8): ${ }^{1} \mathrm{H}-\mathrm{NMR}$ spectral data $\delta$ ppm for compound [4(a-c) and 5(a-c)]

\begin{tabular}{|l|l|l|}
\hline Comp. No. & Structures & \begin{tabular}{l}
$\left.{ }^{1} \mathrm{HNMR} \mathrm{Spectral} \mathrm{data(}{ }^{\delta} \mathrm{ppm}\right)$ \\
\hline $4(\mathrm{a}-\mathrm{c})$
\end{tabular} \\
&
\end{tabular}

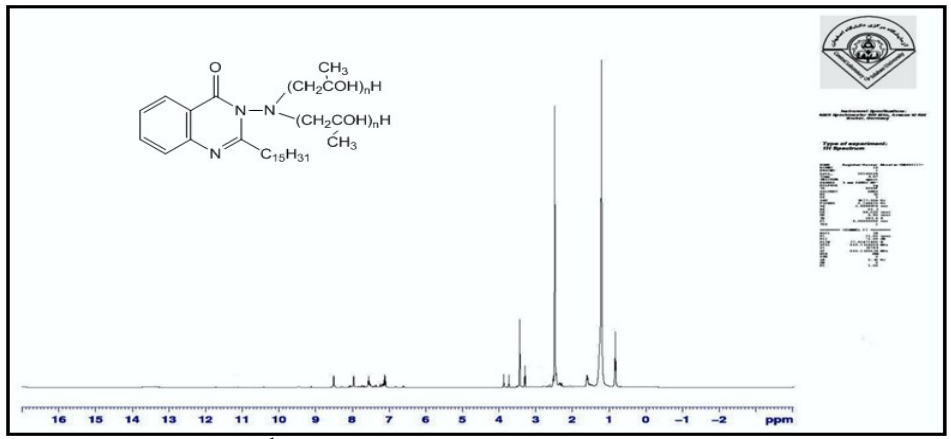

Figure (1) ${ }^{1} \mathrm{H}-\mathrm{NMR}$ spectrum of compound [5(a-c)] 


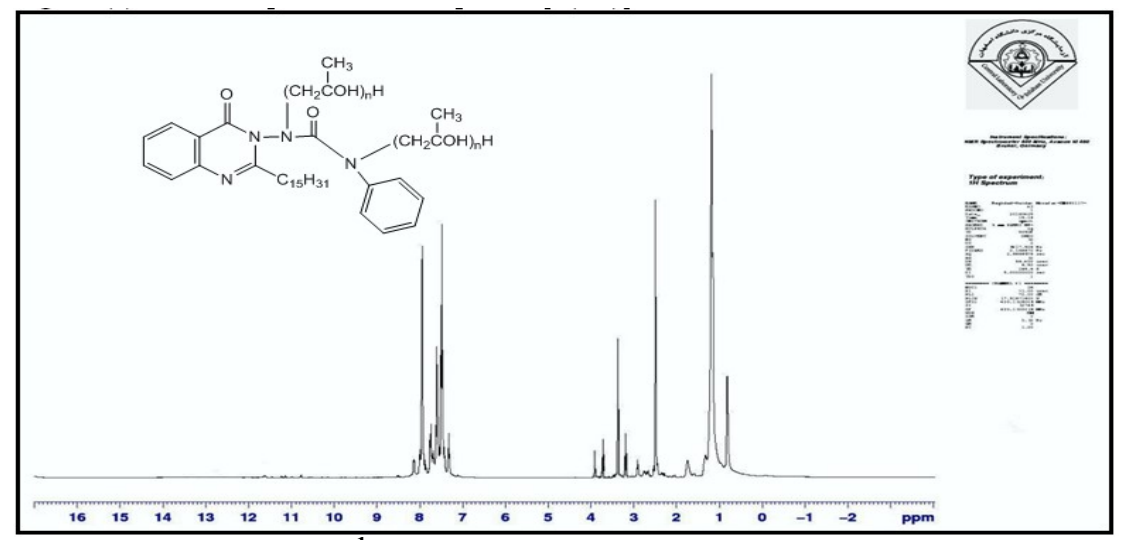

Figure (2) ${ }^{1} \mathrm{H}-\mathrm{NMR}$ spectrum of compound [4(a-c)]

[1]. El-Sayed. R. (Surface active properties and biological activity of novel nonionic surfactants containing pyrimidines and related nitrogen heterocyclic ring systems) Grasas Y Aceites, 59 (2), 110-120, (2008).

[2]. Mohamed, A and Ahmed, M. (Synthesis and antimicrobial activity of some new 2,3-disubstituted quinazoline-4(3H)-ones derivatives) Journal of Chemical and Pharmaceutical Research, 5(5):275-279(2013).

[3]. Redhab A.J Alfraiji, Suaad M.H. Al-Majidi (Synthesis, Characterization and Evaluation of Antimicrobial Activity for New Heterocyclic Derivatives Containing Pentagonal, HexagonalRings) Iraqi Journal of Science, (4B), 55:1694-1707 (2014).

[4]. Fadi, S.E. Nashwa, M., Eman, A., and Gihan, G. (New quinazolinone pyrimidine hybrid: synthesis, anti-inflammatory, and ulcerogenicity studies), Eur J Med Chem...,53, 141-149 (2012).

[5]. Convindaraj, Y., Karthikeyan,V.S., Melanaphura,V., , Setal, G..(Synthesis and In-vivo Anticancer Screening of [(Bis-2chloro ethyl) Amino] Amino] Methyl]-6-8-Dinito-1- (4-substitued Ethyl) - H- quinazoline-4-one derivative). Academica Jornal of Cancer Research 2, 73-77 (2009).

[6]. Elsawy,A.A. , Mohanad,S.K., (Synthesis, reaction and biological evaluation of pentadecanylbenzoxazinone and pentadecanylquinazolinone derivatives), journal of chemical and pharmaceutical research , 4(5), 2755- 2762 (2012).

[7]. Haider M.M. Al-tamimy, Suaad M.H. Al-Majidi (Synthesis and Identification of 2-Pentadecyl-Quinazolinylthiourea (PQT) As Corrosion Inhibitor for Carbon Steel in Acidic Solution) IOSR Journal of Applied Chemistry, 9(8): 36-44 (2016).

[8]. Suaad M.H. Al-Majidi, Redhab A.J Alfraiji, (Synthesis and Evaluation Antimicrobial Activity for some new S- substituted Quinazolinone containing Pentagonal, Hexagonal hetrocyclic ring Rings) Journal of zankoi sulaimani, (part A):1-15 (2015).

[9]. Abdallah, A. Shaaban, K. Abd El-Monem, M. and Ahmed, H. (Synthesis, reactions and biological evaluation of pentadecanyl benzoxazinone and pentadecanyl quinazolinone derivatives) Journal of Chemical and Pharmaceutical Research, 4(5): 2755-2762 (2012).

[10]. Eissa, F. and El-Sayed, R. (Synthesis and evaluation of $\alpha$-hydroxy fatty acid-derived heterocyclic compounds with potential industrial interest) Chemistry Department, Faculty of Science, Benha University, 58(1): 20-28 (2007).

[11]. Adel, S. Sami, G. Abdel-Hamide and Mohamed, M. (Novel 4(3H)-quinazolinone analogs: synthesis and anticonvulsant activity) Med Chem Res, 22:2815-2827 (2013).

[12]. Mohamed, A and Ahmed, M. (Synthesis and antimicrobial activity of some new 2,3-disubstituted quinazoline-4(3H)-ones derivatives) Journal of Chemical and Pharmaceutical Research, 5(5):275-279(2013).

[13]. Maher, A. Mohammad, E. and Jehan, M. (A Novel Series of Biologically Active Quinazolinones through Ring Transformation of 2(5-Nitrofuran-2-yl)-4H-benzo[d][1,3]oxazin-4- one ) International Journal of Scientific \& Engineering Research, 4:218-227(2013).

[14]. Amine, M. and El-Sayed, R. (Synthesis and surface active properties of condensed and non-condensed quinazoline derivatives of industrial application) Indian Journal of Chemistry, 45B: 1020-1027 (2006).

[15]. Suresha, G. Suhas, R. and Channe Gowda, D. (Urea/thiourea derivatives of quinazolinone-lysine conjugates: Synthesis and structure-activity relationships of a new series of antimicrobials) European Journal of Medicinal Chemistry 46: 2530-2540 (2011).

[16]. Yassir, S. (Synthesis Of Some Substituted 1,2,5-Oxadiazino [2- 3,b] Quinazoline And Some 1,3-Oxazole Derivatives ) J. Edu. \& Sci 26(1): 22-30 (2013).

[17]. El-hashash, M. Abdelrahman, T. (Synthesis and behavior of 2-carboxyvinyl-6,8- dibromo-4H-3,1-benzoxazinone toward Nitrogen, Carbone and Sulphur compounds) indian journal of chemistry, 45B:1470-1477 (2006).

[18]. Mahr, A. Dalal, B. and Yaser, A. (Synthesis and evaluation of new 2,3- and 2,4-disubstituted quinazoline derivatives as potential antibacterial and antifungal agents ) Scholars Research Library, 3 (6):147-159 (2011).

[19]. Tripti, S. Shalabh, S. Virendra, K. Srivastava and Ashok, k. (Synthesis, insecticidal and antimicrobial activities of some heterocyclic compounds derivatives of quinazolinone) Indian journal of chemistry, 45B: 2558- 2565 (2006).

[20]. Ismail, T. (Evaluation of some non-ionic surfactants prepared from olive oil having antiseptic activity) International Conference on Medical, Biological and Pharmaceutical Sciences, 4: 4-5, (2013)

[21]. El-sawy, A. and Hebash, K. (preparation and surface active properties of $\alpha$ - acylo succinic acid derivatives from malic acid and fatty acid of crude rice bran oil ) Grasas Y Aceites, 51: 340-347 (2000).

[22]. El-Sukkary, M. El-Sawy, A. and El-Dib, F. (Synthetic Detergents from Crude rice bran oil). Indian Journal of Chemistry. 15:317325. (1987).

[23]. Eissa, F. (Synthesis and evaluation of some surface active agents from long chain fatty amine) Grasas Y Aceites, 58 (4): $379-389$ (2007).

[24]. Monireh, , Ghodsi, M. (One-pot Synthesis of Quinazolinone and Benzamide Derivatives Using $\mathrm{SBA}_{-} \mathrm{Pr}-\mathrm{SO}_{3} \mathrm{H}$ as a Nanoporous Heterogeneous Acid Catalyst) oriental journal of chemistry, 29 (4): 1597-1603 (2013).

[25]. Amine,S. Mahasen, Amal Mahmoud, A., Badr Samy, K. \& S. Gouda Alaa (Synthesis of Surfactants from Pyrazole, Isoxazole, Pyrimidine and Triazine, Incorporating the 1,3,4-Thiadiazole Moiety Having Dyeing and Antimicrobial Activities) Journal of Surfactants and Detergents, 15(2): 179-190 (2012). 